\title{
Study on Suitability of Classical Beauty and Function in Environmental Art Design
}

\author{
Shengyan Xue \\ College of Technology and Art Jingdezhen Ceramic Institute 333001
}

Key words: environmental art design; classical beauty; function; suitability

Abstract: With the continuous development of the economy and the constant improvement of people's living standards, people's requirements for spiritual enjoyment have also been gradually increasing. They have also pursued more spiritual enjoyment brought by environmental arts and gradually raised the demand for environmental art designs. The design of the current urban environment, the design elements are varied. This article analyzes the suitability of classical beauty and function as environmental art design and puts forward corresponding measures.

\section{Introduction}

The constant development of our country's social economy and people's pursuit of the spiritual world is more demanding for environmental art design. In the process of environmental art design, various elements need to be incorporated into it, giving people a kind of beauty to enjoy. People can feel this kind of beauty of vision, sense of smell and so on. In the traditional environmental art design, it is usually to incorporate many elements into the garden design. The garden is used as a design carrier to transform the related things in the garden to achieve a desired spiritual enjoyment. The environment art design the ancient beauty of the United States is mainly produced from the previous landscape design, environmental art design into different elements, it will have different design effects, but also have different beauty, garden art designs into a lot of art manifestation, so that people can experience different beauty.

\section{Related Content Elaboration of Environmental Art Design}

Environmental art designs is a kind of science that rationally plans the environmental and morphological functions of art and design. There are many elements that will be incorporated into the design of environmental art, including the design elements of botany, biology and architecture , etc, organic combination of elements in order to better achieve a kind of beauty to enjoy, but also can experience the functionality from the design. In our country, the traditional classical garden art design incorporates a lot of design elements. The traditional classical gardens are also the ancient people's utilization and transformation of nature under the precondition for relying on the environment, which is also an art manifestation of different dynasties, blending the different cultural essence of the dynasty. With the continuous change of history, people's living standards also continue to rise, aesthetic concepts are constantly changing, and its application of the design elements is different. In the process of ancient garden design, the natural resources mountains , water and pavilions in the environment are usually rebuilt, the relevant design elements are melted, the different elements are organically combined, and designed the environmental art space which is comply with human spirit requirement. Environmental art designs pays more attention to the aesthetic beauty of art and attaches more importance of the combination of various elements. In the process of environmental art design, there are usually more factors to be considered, including economic factors, ecological factors, functional factors and so on.

At present, China's social and economic development is rapid and people's aesthetic conceptions are constantly improving. People pay more attention to the development of environmental resources and the coordinated development of natural environment. Our environmental art design can get more from the traditional landscape design. Therefore, the traditional garden art design elements need to be applied to the modern design, which can effectively to achieve the perfect combination 
of classical beauty and functionality. This is also an aspect that needs attention to the current landscape design. At the same time, environmental art designs should follow the original ecological environment without destroying, and on the basis of rebuilding the environment, increase the aesthetic feeling of the original environment. Environmental art designs work also needs to meet the material and spiritual needs of the general public, meet people's aesthetic standards, and fully coordinate the harmonious development between man and nature.

\section{Cognition of Classical Beauty}

China is a civilized country with a history of 5000 years. With its rich cultural heritage, people's aesthetics will constantly change with the times. Its art development is compatible with the social economy and cultural development. Our country's ancient art fully reflected on the garden design, landscape art design in our country with the development of society continue to develop, at different periods also reflects the different aesthetic design. Garden formation stage is in Yin Zhou and Qin Han Dynasties, this stage of the garden called "court "or "park ", just use some open space as a production and demand environment, the second phase of the development of gardens is Wei, Jin and Northern and Southern Dynasties. The emergence of various ideas of this stage promoted the development of garden art. Among them, the belief in gods was incorporated into the design of gardens, and many temples and gardens appeared. The third stage are also the heyday of garden development during the Sui and Tang dynasties at that time the social and economic development was stable and people lived in abundance. There were also more royal gardens and private gardens, and people's aesthetic conceptions were constantly improving. The fourth stage came to the Me and Qing Dynasties Song and Yuan Dynasties, this period is the maturity of the garden, the rapid development of gardening technology during this period, there are many literary style of garden art, some writers express their own ambitions in the garden, the garden environment also pursuit of artistic conception from the freehand, landscape art is also more pursuit of natural and elegant .

\section{The Relationship between Classical Beauty and Function in Environmental Art Design}

In ancient China's environmental art design, the classical beauty of them is mainly embodied in the design of gardens. The classical beauty of traditional environmental art designs is the experience summed up in the process of continually rebuilding the environment. It has the traditional cultural features, the subtle, dignified expression of classical beauty also serves as a great reference to today's environmental art design and brings people a kind of beautiful enjoyment of the perspective of vision and feeling. In today's environmental art design process, the classical elements will be applied to the design as a traditional culture, as well as the inheritance of traditional culture, making the modern architectural design more unique. At different stages of social development, the concept of people's aesthetic is also different. In the design of environmental art, the concept of the times can also be better able to meet people's aesthetic needs.

To a certain extent, the functional suitability of environmental art designed also to determine whether the environmental design products can continue to develop. The design of environmental art meets the basic needs of people to reflect the value of their design. Therefore, in the design of environmental art, it is applicability is also very important, while paying attention to the beauty of environmental design, but also need to consider its applicability. The layout of the space also is a key factor of the design of the environment. In the design of the space, the distribution of the landscape and the overall environmental structure is also factors that need to be considered [2]. Environmental design station in the human point of view, the design of its applicability also embodies the "people-oriented " designed concept . For example, in the design of environmental art, the design concept of humanization should always be reflected in the design of children's rest facilities to meet the physiological needs of children. To make the design of facilities embody a kind of applicability, from the perspective of environmental protection, functional design to embody the concept of ecology, to understand the living habits of some plants and animals, taking into account the appropriate living area, to provide them with a good living environment. In the process of 
environmental art design, we should pay attention to the applicability and aesthetic design.

The viewing of the scenery is also a dynamic process. In this design process, we need to use the environmental elements to design a certain aesthetic feeling, and we should pay attention to the design of the applicability, including some places for resting and staying. Therefore, in the environmental art design the classical beauty is just as important as the functional suitability design, where design varies depending on the type of environment. For example, some open green spaces need to take into account factors such as the rest of the visitors and pay attention to the applicability of the design.

\section{Applicability Analysis of Classical Beauty and Function of Environmental Art Design}

In the environmental art design, not only to pursue the beauty of design, but also needs / needed to pay attention to applicability, so as to make the environmental art design more valuable, the design of the classical beauty of environmental art and functional design effectively combine not only to meet people's visual enjoyment, but also to meet people's material needs . With the continuous development of the society, people pay more attention to the ecological environment. In the process of designing the environmental art, people should pursue a kind of spiritual enjoyment which is brought by a good ecological environment. It is necessary to consider the economic and scientific aspects, to the performance of the environment we should tak the performance of the rational use of resources into account, but also need to consider the geological conditions, climate and other factors, to improve the value of environmental design . Environmental art is also a comprehensive art design, designers need to integrate their own aesthetic, but also take the various factors of the design into account, with the continuous development of the times, designers need to have a development vision, continuous enhance their professionalism .

\section{Conclusion}

To sum up, the design of classical beauty and function as environmental art designed is equally important. In the process of environmental art design, various factors need to be taken into consideration. There is a need to integrate aesthetics, architecture and other disciplines to bring beauty to people. At the same time, we also need to pay attention to the humanized design, and we need to have a certain cultural atmosphere. With the development of the times, people's aesthetic conceptions are constantly changing. We must fully integrate the development concept of the times.

\section{References}

[1] Wan Ruoyan.Analysis on the suitability of classical beauty and function in the design of ring art [J]. SHANDONG UNIVERSITY OF TECHNOLOGY, 2017, (07) [2] Dai Yijun.Classical Beauty in Fashion Design and the Suitability of Its Function [J] .Packaging World, 2015, (06) 